\title{
Thermal rearrangement of an $N$-hydroxyimidazole thiocarbamoyl derivative as a simple entry into the 4-thioimidazole motif
}

\author{
Luís F. V. Pinto, Gonçalo C. Justino, Abel J. S. C. Vieira, Sundaresan Prabhakar,* and \\ Ana M. Lobo*
}

Chemistry Department, REQUIMTE/CQFB, Faculty of Sciences and Technology, New University of Lisbon, and SINTOR-UNINOVA, 2829-516 Monte de Caparica, Portugal

E-mail: aml@fct.unl.pt

\section{Dedicated to Professor António M. d’A. Rocha Gonsalves on the occasion of his $70^{\text {th }}$ birthday}

\begin{abstract}
A thermal rearrangement of a thio-ester derivative of $N$-hydroxyimidazole gives rise, in a clean reaction, to the corresponding 4- and 2-thiol ester derivatives in a $1: 1$ ratio.
\end{abstract}

Keywords: Sigmatropic rearrangements, 4-thioimidazole, thiocarbamoylation

\section{Introduction}

Imidazole is a heterocycle which appears often in natural products of great importance, such as peptides, amino acids and alkaloids. ${ }^{1}$ Its role in general acid-base catalysis has secured it an undisputed prominence among commonly encountered heterocycles, and explains its crucial action in the mechanism of enzymes. ${ }^{2}$ Often the imidazole ring has suffered further metabolism and may appear substituted with heteroatoms, but to this date there is no simple direct way to introduce a sulfur into position 4 of such a heterocycle. ${ }^{3}$

In connection with the need to introduce a sulfur, we sought to use a thermally induced rearrangement as was earlier disclosed by us for ene-hydroxylamine derivatives. ${ }^{4,5}$ The sulfur atom is, in this strategy, part of a reactive thiocarbonyl, a functional group which can modulate molecular reactivity, and has found ample use in synthesis. ${ }^{6}$ We report here our results on a formal sigmatropic rearrangement to achieve this goal. 


\section{Results and Discussion}

The substrate selected, the imidazole thiocarbonyl derivative 1, could, in principle through a [3,3]-sigmatropic rearrangement, deliver the sulfur to C-4 of the heterocycle to give rise to 2 (Scheme 1, a). By a simple retrosynthesis access to 1 was reduced to the synthesis of $N$ hydroxyimidazole (3), since there are compounds of type 4 commercially available (Scheme 1, b).<smiles>[Z]C(=O)Sc1c[nH]cn1</smiles>

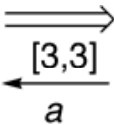

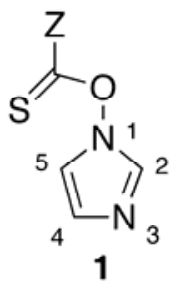<smiles>O[n+]1ccncn1</smiles>

3<smiles>[Z]C(=[SH+])[TlH]</smiles>

$\mathrm{L}=$ leaving group

Scheme 1. Retrosynthetic analysis for 2 involving a [3,3]-sigmatropic rearrangement.

The actual synthesis of compound $\mathbf{1}\left(\mathrm{Z}=\mathrm{NMe}_{2}\right)$ is shown in Scheme 2, where for the steps leading to 3 literature procedures were used. ${ }^{7,8}$ The appropriate thiocarbamoyl chloride was then reacted with compound $\mathbf{3}$ to afford target $\mathbf{1}$ in $88 \%$ yield as a low melting yellow solid.

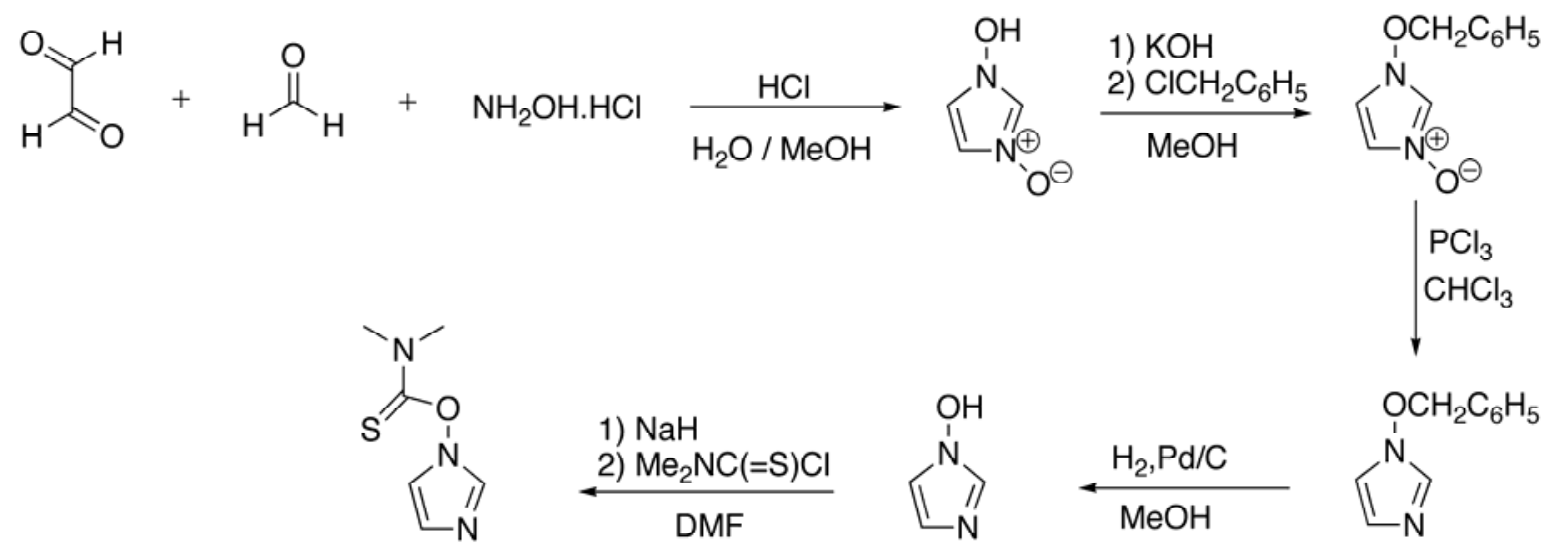

Scheme 2. Synthesis of 1.

The rearrangement of 1 was initially conducted in a $0.09 \mathrm{M}$ solution in chlorobenzene at 140 ${ }^{\circ} \mathrm{C}$ and found by TLC and ${ }^{1} \mathrm{H}$ NMR monitoring to be completed within one hour, leading only to two products, namely the expected compound 2 and another compound 5 in ratio of 1 : 1 (Scheme 3). 


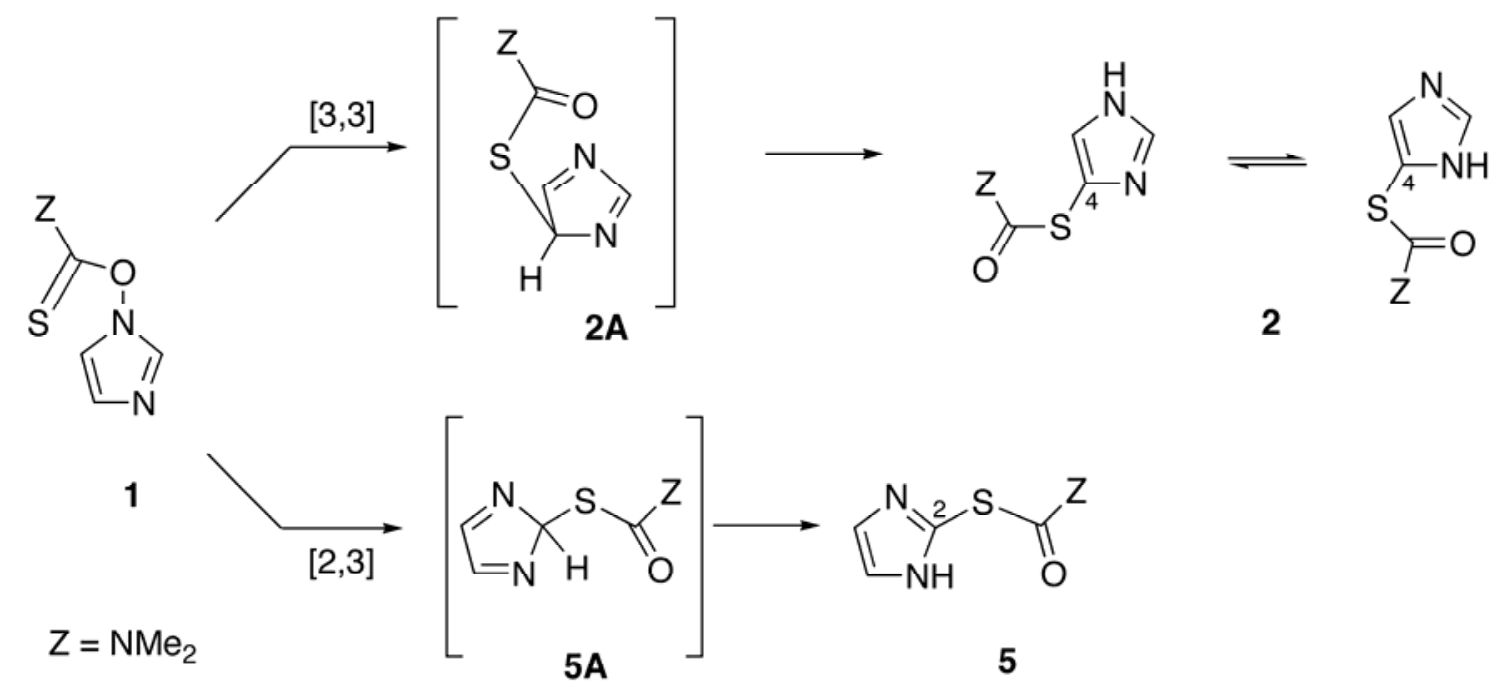

Scheme 3. Thermal rearrangement of compound $\mathbf{1}$ to give the isomers $\mathbf{2}$ and $\mathbf{5}$.

Mass spectrometry of $\mathbf{2}$ and $\mathbf{5}$ showed that both products were isomeric with the starting material, with an $\mathrm{M}^{+}$consistent with the molecular formula $\mathrm{C}_{6} \mathrm{H}_{9} \mathrm{~N}_{3} \mathrm{OS}$. While the IR showed the presence in both of carbonyl stretching at 1667 (for 2) and $1681 \mathrm{~cm}^{-1}$ (for 5), the ${ }^{1} \mathrm{H}-\mathrm{NMR}$ showed that while the thio group had moved to the expected position 4 in 2 (absence of the proton at carbon-4), in compound 5 the same group had occupied the position at carbon-2 (absence of the proton at carbon-2).

Reactions in other solvents were also assessed and the results are collected in the Table 1. The ratio of products remained close to 1:1 (Table 1, $c f$. entries 1 to 4), except for the reaction conducted in benzene where the yield of compound $\mathbf{5}$ dropped 13\% in relation to that of $\mathbf{2}$ in a slow reaction over six days (entry 5).

Table 1. Thermal rearrangement of compound $\mathbf{1}$ giviing compounds $\mathbf{2}$ and $\mathbf{5}$

\begin{tabular}{ccccccc}
\hline Entry & Solvent ${ }^{\mathrm{a}}$ & $\begin{array}{c}\text { Temperature } \\
{\left[{ }^{\circ} \mathrm{C}\right]}\end{array}$ & Time & $\begin{array}{c}\text { Yield 2 }^{\mathrm{b}} \\
{[]^{\mathrm{b}}}\end{array}$ & $\begin{array}{c}\text { Yield 5 }^{\mathrm{b}} \\
{[\%]^{\mathrm{b}}}\end{array}$ & $\begin{array}{c}\text { Ratio } \\
\mathbf{2}: \mathbf{5}\end{array}$ \\
\hline 1 & Diphenyl ether & 265 & $3 \mathrm{~min}$ & 50 & 50 & $1: 1$ \\
2 & $o$-Dichlorobenzene & 180 & $30 \mathrm{~min}$ & 50 & 50 & $1: 1$ \\
3 & Chlorobenzene & 140 & $60 \mathrm{~min}$ & 50 & 47 & $1.06: 1$ \\
4 & Toluene & 110 & $24 \mathrm{~h}$ & 45 & 43 & $1.05: 1$ \\
5 & Benzene & 80 & $6 \mathrm{~d}$ & 47 & 34 & $1.38: 1$ \\
\hline
\end{tabular}

${ }^{\mathrm{a}}$ Solutions $0.09 \mathrm{M} .{ }^{\mathrm{b}}$ Isolated yields.

A possible mechanism is presented in Scheme 3. While compound $\mathbf{2}$ appears to result from a straighforward [3,3]-sigmatropic rearrangement via 2A, compound 5 could result from a [2,3]sigmatropic rearrangement through an intermediate $\mathbf{5 A} .^{9}$ The intermediacy of a possible radical 
pathway cannot be ruled out. If radicals are indeed involved, the fact that two canonical equivalent forms are possible for Im2 (Scheme 4) would favour formation of 2, whereas preferential formation of $\mathbf{5}$ would be expected on account of spin densities alone. The observed 1:1 ratio of products could then imply that both effects cancel each other.

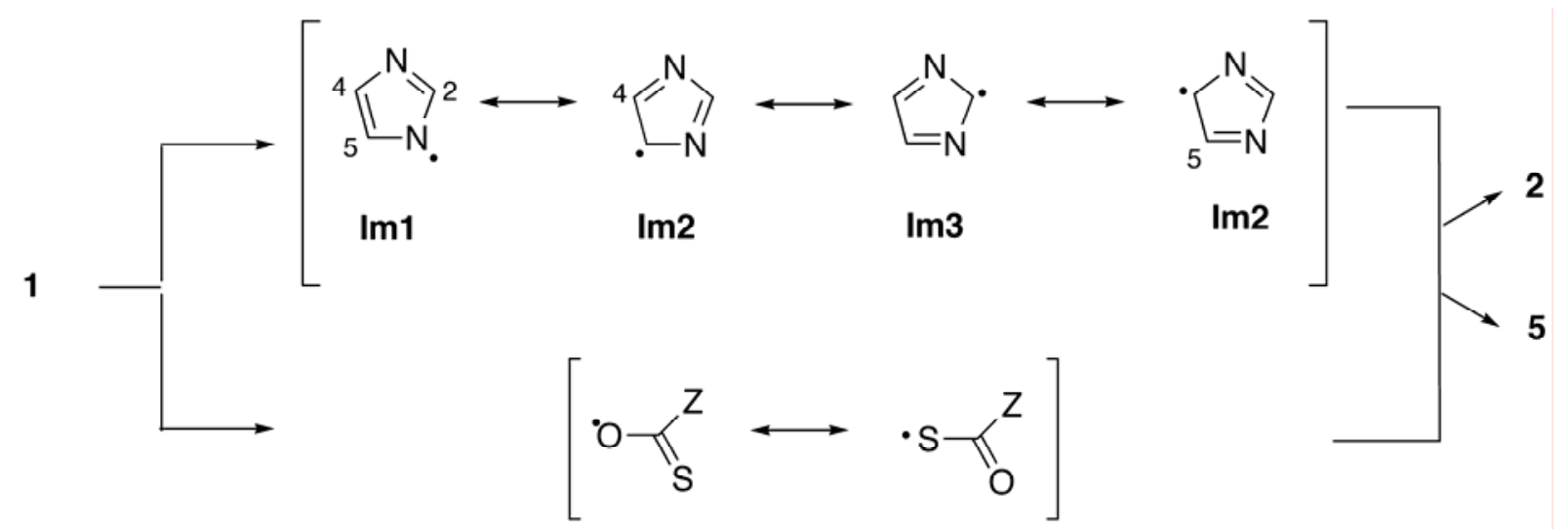

Scheme 4. Possible radicals involved in the reaction pathway for compounds 2 and $\mathbf{5}$.

The calculated spin density of the imidazoyl radical, using 6-311++G(3df,3pd), (cf. Experimental - General Procedures) at carbon-4 (and -5) is 0.35, while at carbon-2 this value increases to 0.50, giving a ratio of spin densities at C-4 (Im2)/C-2 (Im3) of 1.4:1. Inspection of earlier literature shows a similar trend, ${ }^{10}$ and Solé's calculations of the spin density of a $\pi$-type imidazoyl radical at C-4 (and C-5) found a value of 0.0952, while at C-2 the value increased to $0.1607,{ }^{11}$ resulting in a similar ratio of 1.2:1, closer to the ratio of products found. Of course if radicals are indeed involved they would have to be associated within a tight radical pair, since no dimeric products were detected.

\section{Experimental Section}

General Procedures. Melting points were determined with a Reichert Thermovar hot-stage microscope and are uncorrected. Chromatography was performed using E. Merck silica gel 60 (70-230 mesh). Preparative thin-layer chromatography (PTLC) was performed on plates precoated with silica gel $\mathrm{GF}_{254}(0.5 \mathrm{~mm})$. Infrared spectra (IR) were recorded with a Fourier Perkin-Elmer 157G and 683 infrared spectrometers and the frequencies reported in $\mathrm{cm}^{-1}$. Nuclear magnetic resonance spectra $\left({ }^{1} \mathrm{H}\right.$ NMR and ${ }^{13} \mathrm{C}$ NMR) were obtained with a Bruker ARX 400. Chemical shifts are reported in ppm downfield from tetramethylsilane. Mass spectra were obtained on a mass spectrometer GC-TOF Micromass GTC. All solvents were purified by standard methods. 
Calculations were performed with the Gaussian 03 software $^{12}$ at the DFT level using the hybrid functional B3LYP ${ }^{13}$ and the 6-311++G(3df,3pd) basis set. ${ }^{14}$ Full geometry optimization was performed for all species in the gas phase, and the optimized geometries were used for the calculations.

\section{Thiocarbamoylation of $\boldsymbol{N}$-hydroxy-imidazole to afford thiocarbamoyl imidazole 1}

To a stirred solution of $N$-hydroxyimidazole (3) (20 mg, $0.24 \mathrm{mmol}$ ) in dry DMF (2 mL) was added $\mathrm{NaH}$ (60\% mineral oil dispersion) (10 mg, $0.24 \mathrm{mmol}$ ). After the liberation of $\mathrm{H}_{2}$ ceased (10 m), N,N-dimethylthiocarbamoyl chloride (30 mg, $0.24 \mathrm{mmol})$ in DMF (0.5 mL) was added dropwise, and the reaction allowed to proceed for a further $10 \mathrm{~min}$. The reaction was stopped by adding $\mathrm{H}_{2} \mathrm{O}(2 \mathrm{~mL})$ and extracting the mixture with AcOEt ( $\left.5 \times 2 \mathrm{~mL}\right)$, separating and drying the organic phase with $\mathrm{Na}_{2} \mathrm{SO}_{4}$ and evaporating the solvent under vacuum. The solid residue obtained was purified by column chromatography $\left(\mathrm{SiO}_{2}, \mathrm{EtOAc}\right)$ to yield the title compound $\mathbf{1}$, as a yellow solid, $35 \mathrm{mg}$ (88\%); mp 43-45 ${ }^{\circ} \mathrm{C}\left(\mathrm{Et}_{2} \mathrm{O}\right)$; IR (neat) v: 3115, 2926, 2854, 1556, 1400 1281, 1259, 1176, $1066 \mathrm{~cm}^{-1}$; ${ }^{1} \mathrm{H}-\mathrm{NMR}\left(\mathrm{CDCl}_{3}, 400 \mathrm{MHz}\right) \delta_{\mathrm{H}}: 7.56$ (s, 1H), $7.02(\mathrm{~s}, 2 \mathrm{H}), 3.43$ (s, 3H), 3.34 (s, 3H); ${ }^{13} \mathrm{C}-\mathrm{NMR}\left(\mathrm{CDCl}_{3}, 100.62 \mathrm{MHz}\right) \delta_{\mathrm{C}}: 186.7(\mathrm{C}=\mathrm{S}), 132.7,125.0,117.2,44.9$, 38.8; MS (FI): $\mathrm{m} / \mathrm{z}=172\left([\mathrm{M}+\mathrm{H}]^{+}, 100\right), 72\left(\mathrm{C}_{3} \mathrm{H}_{6} \mathrm{NO}, 70\right)$. Calcd for $\mathrm{C}_{6} \mathrm{H}_{9} \mathrm{~N}_{3} \mathrm{OS}$ : C, 42.09; $\mathrm{H}$, 5.30; N, 24.54; S, 18.73\% Found: C, 42.09; H, 5.19; N, 24.73; S, 18.69\%

Thermal rearrangement of imidazole (1). In a round bottom flask a solution of $\mathbf{1}$ (30 mg, 0.18 $\mathrm{mmol})$ in chlorobenzene $(2 \mathrm{~mL}$ ) was heated to reflux until disappearance of the starting material (60 min), by ${ }^{1} \mathrm{H}-\mathrm{NMR}$ and TLC monitoring (AcOEt/MeOH, 4:1). The solvent was then evaporated and the residue purified by preparative thin layer chromatography to yield compounds 2 and 5. Results with other solvents followed an identical protocol (Table).

4-Thiol-imidazole derivative (2). Yield: $15.0 \mathrm{mg}$ (50\%); colourless solid; Rf 0.19 (AcOEt/MeOH, 8:1); mp 121-123 ${ }^{\circ} \mathrm{C}$ (AcOEt); IR (neat) v: 3119, 2994, 2921, 1667 (C=O), 1487, 1406, 1367, 1258, $1100 \mathrm{~cm}^{-1} ;{ }^{1} \mathrm{H}-\mathrm{NMR}\left(\mathrm{CDCl}_{3}\right) \delta_{\mathrm{H}}: 9.46$ (s, $\left.1 \mathrm{H}, \mathrm{NH}\right), 7.52(\mathrm{~s}, 1 \mathrm{H}), 7.12$ (s, $1 \mathrm{H}), 3.08$ (s, 3H, $\left.\mathrm{CH}_{3}\right), 2.99\left(\mathrm{~s}, 3 \mathrm{H}, \mathrm{CH}_{3}\right) ;{ }^{13} \mathrm{C}-\mathrm{NMR}\left(\mathrm{CDCl}_{3}\right) \delta_{\mathrm{C}}: 167.7(\mathrm{C}=\mathrm{O}), 137.3,125.6$, 123.3, 37.0; MS (FI): $m / z=171\left(\mathrm{M}^{+}, 100\right), 72\left(\mathrm{C}_{3} \mathrm{H}_{6} \mathrm{NO}, 70\right)$; HRMS: $\mathrm{m} / \mathrm{z}=171.046998\left(\mathrm{M}^{+}\right)$, calcd for $\mathrm{C}_{6} \mathrm{H}_{9} \mathrm{~N}_{3} \mathrm{OS} 171.046634$.

2-Thiol-imidazole derivative (5). Yield: $14.1 \mathrm{mg}$ (47\%); white-brownish solid; Rf 0.33 (AcOEt/MeOH, 8:1); mp 133-135 ${ }^{\circ} \mathrm{C}$ (AcOEt); IR (neat) v: 3116, 2998, 2924, 2854, 1681 $(\mathrm{C}=\mathrm{O}), 1550,1425,1366,1257,1092 \mathrm{~cm}^{-1}$; ${ }^{1} \mathrm{H}-\mathrm{NMR}\left(\mathrm{CDCl}_{3}\right) \delta_{\mathrm{H}}: 9.46$ (s, 1H, NH), 7.13 (s, 2H), 3.05 (s, 3H, $\left.\mathrm{CH}_{3}\right), 3.03$ (s, 3H, $\left.\mathrm{CH}_{3}\right) ;{ }^{13} \mathrm{C}-\mathrm{NMR}\left(\mathrm{CDCl}_{3}\right) \delta_{\mathrm{C}}: 165.0(\mathrm{C}=\mathrm{O}), 134.0,124.2$, 37.0; MS (FI): $m / z=172\left(\mathrm{M}^{+}+\mathrm{H}, 100\right), 72\left(\mathrm{C}_{3} \mathrm{H}_{6} \mathrm{NO}, 70\right)$; HRMS: $m / z=171.046634\left(\mathrm{M}^{+}\right)$, calcd for $\mathrm{C}_{6} \mathrm{H}_{9} \mathrm{~N}_{3} \mathrm{OS} 171.046677$. 


\section{Acknowledgements}

We thank Fundação para a Ciência e Tecnologia (FC\&T, Lisbon, Portugal) for partial financial support (Project POCTI/QUI/36456). One of us (L. F. V. P.) is grateful for the award of a doctoral fellowship from FC\&T.

\section{References and Notes}

1. Review on imidazole and substituted imidazoles: Grimmett, M. R. In Comprehensive Heterocyclic Chemistry II; Katritzky, A. R.; Rees, C. W. Eds.; Elsevier: Oxford, 1996; Vol. 3, p 190.

2. (a) Dugas, H. Biorganic Chemistry - A Chemical Approach to Enzyme Action, 3rd Edn.; Springer India: New Delhi, 2003; p 159. (b) Domling, A.; Beck, B.; Herdtwerck, E.; Antuch, W.; Oefner, C.; Yehia, N.; Gracia-Marques, A. Arkivoc 2007, (iii), 99.

3. (a) Zoete, V.; Bailly, B.; Catteau, J.-P.; Bernier, J.-L. J. Chem. Soc, Perkin Trans 1 1997, 2983. (b) Biernaz, C.; Cornwell, M. J. Tetrahedron 1993, 34, 939. (c) Asinger, F.; Sans, A; Offermanns, H.; Krings, P.; Andree, H. Justus Liebigs Ann. Chem. 1971, 744, 51. (d) Caille, J. C.; Didierlaurent, S.; Lefrançois, D.; Lelièvre, M. H.; Sury, C.; Aszodi, J. Synthesis 1995, 6, 635. (e) Spaltenstein, A.; Holler, T. P.; Hopkins, P. B. J. Org. Chem. 1987, 52, 2977. (f) Zyabrev, V. S.; Kiselev, V. V.; Romanenko, E. O.; Drach, B. S. Zh. Org. Khim. 1994, 5, 715.

4. (a) Reis, L. V.; Lobo, A. M.; Prabhakar, S. Tetrahedron Lett. 1994, 35, 2747. (b) Reis, L. V.; Lobo, A. M.; Prabhakar, S.; Duarte, M. P. Eur. J. Org. Chem. 2003, 190. (c) Duarte, M. P.; Mendonça, R. F.; Prabhakar, S.; Lobo, A. M. Tetrahedron Lett. 2006, 1173.

5. Pereira, M. M. A.; Santos, P. P. In The Chemistry of Hydroxylamines, Oximes and Hydroxamic Acids; Rappoport, Z.; Liebman, J. F. Eds.; John Wiley: London, 2008; p 343.

6. (a) Crich, D.; Quintero, L. Chem. Rev. 1989, 89, 1413. (b) Motherwell, W. B.; Crich, D. Free Radical Chain Reactions in Organic Synthesis; Academic Press: London, 1992; p 85. (c) Barton, D. H. R.; Parekh, S. I. Half a Century of Free Radical Chemistry; Cambridge University Press: Cambridge, 1992. (d) Curran, D. P.; Porter, N. A.; Giese, B. Stereochemistry of Radical Reactions; VCH: Weinheim, 1995; p 188.

7. Laus, G.; Stadlwieser, J.; Klotzer, W. Synthesis 1989, 773.

8. Eriksen, B. L.; Vedso, P.; Morel, S.; Begtrup, M. J. Org. Chem. 1998, 63, 12.

9. For Claisen and thio-Claisen rearrangements' mechanism, see: (a) Arnaud, R.; Dillet, V.; Pelloux-Léon, N.; Vallée, Y. J. Chem. Soc, Perkin Trans 2 1996, 2065. (b) Arnaud, R.; Vallée, Y. J. Chem. Soc, Perkin 2 1997, 2373. (c) Ganem, B. Angew. Chem. Int. Ed. Engl. 1996, 35, 936. (d) Gajeswki, J. J. Acc. Chem Res. 1997, 30, 219. (e) Rehbein, J.; Hiersemann, M. In The Claisen Rearrangement: Methods and Applications, Hiersemann, M.; Nubbemeyer, U., Eds.; Wiley-VCH: Weinheim, 2007; p 525. 
10. Lassmann, G.; Eriksson L. A.; Himo, F.; Lendzian F.; Lubitz, W. J. Phys. Chem. A 1999, 103, 1283.

11. Bofill, J. M.; Olivella, S.; Solé, A. J. Am. Chem. Soc. 1989, 111, 7740.

12. Gaussian 03, Revision E.01, Frisch, M. J.; Trucks, G. W.; Schlegel, H. B.; Scuseria, G. E.; Robb, M. A.; Cheeseman, J. R.; Montgomery, Jr., J. A.; Vreven, T.; Kudin, K. N.; Burant, J. C.; Millam, J. M.; Iyengar, S. S.; Tomasi, J.; Barone, V.; Mennucci, B.; Cossi, M.; Scalmani, G.; Rega, N.; Petersson, G. A.; Nakatsuji, H.; Hada, M.; Ehara, M.; Toyota, K.; Fukuda, R.; Hasegawa, J.; Ishida, M.; Nakajima, T.; Honda, Y.; Kitao, O.; Nakai, H.; Klene, M.; Li, X.; Knox, J. E.; Hratchian, H. P.; Cross, J. B.; Bakken, V.; Adamo, C.; Jaramillo, J.; Gomperts, R.; Stratmann, R. E.; Yazyev, O.; Austin, A. J.; Cammi, R.; Pomelli, C.; Ochterski, J. W.; Ayala, P. Y.; Morokuma, K.; Voth, G. A.; Salvador, P.; Dannenberg, J. J.; Zakrzewski, V. G.; Dapprich, S.; Daniels, A. D.; Strain, M. C.; Farkas, O.; Malick, D. K.; Rabuck, A. D.; Raghavachari, K.; Foresman, J. B.; Ortiz, J. V.; Cui, Q.; Baboul, A. G.; Clifford, S.; Cioslowski, J.; Stefanov, B. B.; Liu, G.; Liashenko, A.; Piskorz, P.; Komaromi, I.; Martin, R. L.; Fox, D. J.; Keith, T.; Al-Laham, M. A.; Peng, C. Y.; Nanayakkara, A.; Challacombe, M.; Gill, P. M. W.; Johnson, B.; Chen, W.; Wong, M. W.; Gonzalez, C.; and Pople, J. A.; Gaussian, Inc., Wallingford CT, 2004.

13. Becke, A. D. J. Chem. Phys. 1993, 98, 5648 .

14. Krishnan, R.; Binkley, J. S.; Seeger, R.; Pople, J. A. J. Chem. Phys. 1980, 72, 650. 